\title{
Examination Of Factors Affecting The Utilization Of Information Technology
}

\author{
Akira Hiro', Kenzo Kei ${ }^{2}$ \\ Universitas Toyama \\ Japan \\ e-mail: akira hiro@yahoo.com, kenzo.kei@yahoo.com
}

To cite this document:

Akira Hiro, \& Kenzo Kei. (2020). Examination Of Factors Affecting The Utilization Of Information Technology. IAIC Transactions on Sustainable Digital Innovation (ITSDI), 2(1), 61-68.

DOI : https://doi.org/10.34306/itsdi.v2i1.353

\begin{abstract}
Data innovation incorporates $P C$ innovation and correspondence innovation used to measure and disperse data, both money related and non-monetary. Interests in data innovation require huge assets and will increment from year to year. The measure of assets gave expects associations to utilize data innovation. The powerful utilization of data innovation should be possible if every person in the association can utilize this innovation. This article gives a clarification of the components that impact the utilization of data innovation by directing a hypothetical report.

In view of hypothetical investigations and an audit of the aftereffects of past examination identified with the utilization of data innovation, there are six factors that impact the utilization of data innovation, in particular: social variables, influence factors, multifaceted nature factors, task appropriateness, long haul result factors and encouraging conditions.
\end{abstract}

Keywords: Information Technology, Information Technology Utilization and Information Technology Utilization Factors. 


\section{Introduction}

The requirement for quick, solid and exact data in a climate brimming with vulnerability is totally fundamental. This need can be met if the organization puts resources into data innovation. Sabherwal and King (1991); Grover and Goslar (1993) demonstrate observationally that data innovation is a way to lessen the vulnerability of an authoritative climate. Interests in data innovation in an association are generally pointed toward making a positive commitment to the presentation of individual individuals from associations and organizations. Exploration by Mahmood and Mann (1993); Barua et al (1995): Brynjolfsson and Hitt (1996); Mitra and Chaya (1996); Rai et al (1997) gives experimental proof that interest in data innovation adds to the exhibition and profitability of an association.

Data innovation, particularly PC innovation, can possibly improve individual and authoritative execution, in this way numerous chiefs put assets in data innovation. Notwithstanding, it must be understood that interest in data innovation requires enormous assets. Cockroach (1991) and Strassman (1996) give proof that interest in data innovation requires huge assets and will increment from year to year. The measure of assets spent by organizations in putting resources into data innovation expects associations to utilize data innovation. As indicated by Teddy Jurnali (2001), the measure of assets contributed and the chance of danger emerging in the utilization of data innovation, particularly the improvement of data frameworks in an association, causes data framework designers to comprehend the components that can guide hierarchical individuals to utilize data frameworks successfully. Chiefs and operational representatives must have the option to utilize accessible application applications, learn firsthand parts of equipment and programming and receive data innovation as per the requirements of their obligations. The utilization of data frameworks by all individuals is one proportion of the achievement of creating data frameworks in the association concerned.

Data innovation can be used adequately if individuals in the association can utilize the innovation appropriately. Accordingly it is significant for authoritative individuals to comprehend and foresee the helpfulness of the framework. The degree of profitability in the data innovation area will be little if representatives neglect to acknowledge the innovation or take advantage of it as per their abilities (Lucas and Spitler, 1999). Comprehension of the utilization of data innovation should be possible by understanding the elements that can influence the utilization of data innovation. This article plans to examine what variables can impact the utilization of data innovation, particularly PC innovation, in light of hypothetical investigations and pertinent past examinations. The conversation starts with a writing survey in regards to what data innovation is trailed by the hypothesis that underlies it, the utilization of data innovation and what variables impact it, including past investigations.

\section{Research Method}

Data innovation incorporates PC innovation (figuring innovation) and correspondence innovation (correspondence innovation) which is utilized to measure and scatter data whether it is budgetary or non-monetary (Bodnar and Hopwood, 1995). So it very well may be said that data innovation is any coordinated methods or devices that are utilized to channel information, measure and communicate or present electronically into data in different organizations that are helpful to the client.

Interests in data innovation are expected to create quick, exact, precise and complete data, both inside data and outside data and to increase an upper hand, anyway these speculations require enormous assets and have dangers and dangers of misfortune from the utilization of data innovation itself. To settle on choices that are more compelling and useful, framework designers need to have a superior comprehension of the variables that impact the 
utilization of data innovation (Jackson et al, 1997). Complete comprehension of a framework is the way in to the viability of utilizing the framework, with the goal that the disappointment of a framework is brought about by an absence of comprehension of the framework by representatives (Mortensen, 1988). To have the option to see well the connection between data innovation and individual execution, Sugeng and Nur Indriantoro (1998) contend that there is a requirement for a solid thorough hypothetical model in which there are factors that altogether become immediate and aberrant indicators of individual execution. Fishbein and Ajzen's Theory of Reasoned Action (1975) states that an individual's conduct is a gauge of the force and activity where an individual will utilize data innovation on the off chance that is helpful and improves execution thus should. Ficher (1996 in Silvia, 2001) states that the advantages of new data innovation can be felt if clients of data innovation are "mindful" of its advantages. Moreover, the quick advancement of data innovation in the workplace has utilized data innovation as a pressing issue.

\subsection{Formula/Algorithm [optional]}

The term information systems includes the use of information technology for managers. Thompson et al $(1991 ; 1994)$ defines the use of technology as the benefits expected by users of information systems in carrying out their duties where the measurement is based on the intensity of utilization, frequency of use and the number of applications or software used. . Meanwhile, Teddy Jurnali (2001) argues that the use of technology is related to the behavior in using the technology to carry out his duties. The theory of attitudes and behavior (theory of attitudes and behavior) from Triandis (1980) states that the use of information technology, especially personal computers (PC: Personal computers) by workers who have optional knowledge in an environment, will be influenced by individual feelings. affect) on PC use, social norms in the workplace that pay attention to PC use, habits related to computer use, the expected individual consequences (consequences) of PC use and facilitating conditions in a different environment. conducive to $P C$ usage.

Thompson et al (1991) tested some PC utilization models using Triandis' attitudes and behavior theory. The test results show that there is a positive and significant relationship between social and utilization factors, an insignificant relationship between affect and utilization, a negative relationship between complexity and utilization, and a positive relationship between job fit and utilization. . In addition, the research of Thompson et al (1991) also found a significant relationship between long term consequences and utilization and the relationship between facilitating conditions and utilization showed a negative and weak relationship. Furthermore, the research model conducted by Thompson et al (1991) can be described below :

Based on the framework developed by Thompson (1991), there are six factors that influence the use of information technology, namely social factors, affect, complexity, suitability of tasks, long-term consequences and facilitating conditions. The following is a discussion of the six factors and the results of previous studies related to these six factors.

\subsection{Literature Review}

Triandis (1980) defines social factors as individual internalization of subjective cultural group references and specifies the interpersonal agreement that individuals have attempted with others in special social situations. Subjective culture contains norms (norms), roles (roles) and values (values). Social factors that influence the use of information technology developed by Thompson et al (1991) include statements about:

a. the number of colleagues who use information technology, especially computer technology in carrying out daily tasks / jobs b. There are senior managers / superiors who assist / 
encourage both in introducing and utilizing information technology. c. companies are very helpful in the utilization / use of information technology.

Davis et I (1989) argues that the relationship between social norms and the use / utilization of information technology is not significant. Meanwhile, Thompson et al (1991) found that social factors have a significant influence on computer use which is consistent with Triandis (1980) theory. In Indonesia, Rahmi Qadri (1997) and Thai Fung Jin (2002) found that there is a positive and significant relationship between social factors and the use of information technology.

\subsection{Hypotheses [optional]}

Triandis (1980) explains the affect factor as feelings of joy, joy, pleasure or depression, disgust, displeasure and hate associated with certain individuals in the use of information technology. According to Ghoodhue (1988), most information systems researchers do not make a distance between the affective component of the attitude (which has a connotation of likes or dislikes) and the cognitive component or belief (information that a person holds about an object, issue or person). Lucas (1978) used a mixed cognitive component and influence questions to measure a single attitude construct. Controversy arises between researchers who acknowledge the difference between the affective and the cognitive component. Bunkrant and Page (1982) suggest that although there may be a theoretical justification for the separation of cognitive from affective components, when used for measurement, both should be treated as the same construct. Thompson et al developed an instrument to measure the Affect factor of the use of information technology which includes three statements, namely:

a. the work that is done becomes more attractive and easier if you use information technology

b. there is a feeling of preferring to work when using information technology, especially computer technology

c. Information technology, especially computer technology, can be useful for several types of work but not for the type of work you want to do (negative statement / vice versa).

Thompson et al (1991) found that affect did not have a significant effect on the use of information technology, while Davis et al (1989) found a significant effect between affect and the use of information technology supported by research conducted by Rahmi Qadri (1997). While the results of research conducted by Thai Fung Jin (2002) are consistent with research conducted by Thompson et al (1991) that affect does not have a significant effect on the use of technology. This is also consistent with Triandis (1980) theory.

\section{Findings}

Complexity is defined as the perceived level of innovation as relatively difficult to understand and use (Rogers and Shoemaker, 1971 in Rahmi Qadri, 1997). Thompson et al (1991) developed four questions to determine the effect of complexity on the use of information technology, namely:

a. The use of information technology in carrying out daily tasks / work takes up a lot of time

b. Working with information technology is so complicated that it is difficult to understand and understand how to use it.

c. Using information technology, especially computer technology to enter data, takes a lot of time

d. It took a long time to use information technology.

Research conducted by Tornatzky and Klein (1982) found that the more complex the innovation made in an information technology, the lower the adoption or acceptance rate. If the use of information technology can be demonstrated in the context of innovation adoption, the results of this study suggest a relationship between complexity and utilization. Thompson 
et al (1991) also stated that there is a significant and negative influence between complexity and the use of information technology.

\subsection{Problem}

Thompson et al (1991) explained that task suitability is related to the extent to which an individual's ability to use information technology to improve individual performance in carrying out tasks. The relationship between task suitability and the use of information technology has empirical support. Thompson et al (1991) also developed six questions to determine the effect of task suitability on the use of information technology. The six questions include:

a. utilizing information technology does not affect job performance (negative questions that will later score reversed)

b. By utilizing information technology can reduce the time needed to complete work.

c. Utilizing information technology can improve the quality of work.

d. Utilizing information technology can increase job effectiveness

e. The amount of output produced will increase if it utilizes information technology

f. Using information technology can assist in completing tasks.

Research conducted by Tornatsky and Klein (1982) found that an innovation may be adopted when the innovation is in accordance with individual work responsibilities. Davis et al (1989) stated that there is a strong relationship between task suitability and the use of information technology. This is also supported by Thompson et al (1991) who found a significant influence between task suitability and the use of information technology.

\subsection{Research Implementation}

Long-term consequences are defined as the results obtained in the future, such as increased flexibility, changing jobs or increased opportunities for more meaningful work. To determine the effect of long-term consequence factors with the use of information technology, Thompson et al (1991) developed six instruments, namely:

a. Using information technology makes work more challenging

b. Using information technology will increase the chances of finding preferred assignments in the future.

c. Using information technology makes work more varied.

d. Using information technology will increase the opportunity to get a more important job so that you can apply your abilities

e. Using information technology will increase the opportunity to perform different tasks

f. Using information technology can increase the chances of getting a better position.

Previous research conducted by Beatty (1986 in Thai Fung Jin, 2002) found a strong positive relationship between long-term consequences and the use of information technology. Thompson et al (1991) also found the same result. There are some exceptions to some individuals, namely that motivation to adopt and use information technology may have more to do with planning for the future than to addressing the need for today.

\subsubsection{Facilitation Condition Factors}

Facilitating conditions are defined as objective factors outside the environment that make it easier for users to act / work (Triandis, 1980). In the context of the use of information technology, support for users is one type of facilitating condition that can affect the use of information technology. Schlutz and Slevin (1975) proved that support or 
resistance is one of the factors that influence utilization. This is supported by Robey (1979) who found a positive correlation between support / resistance and the use of a system. Meanwhile, Thompson et al (1991) found no positive relationship between supporting conditions and the use of information technology. Research conducted by Thai Fung Jin (2002) also supports the research of Thompson et al (1991).

\section{Conclusion}

Based on the description above and the results of previous studies, it can be concluded that:

1. Information technology includes computer technology (computing technology) and communication technology (communication technology) which is used to process and disseminate information, whether financial or non-financial.

2. Utilization of information technology is the benefit expected by users of information systems in carrying out their duties where the measurement is based on the intensity of utilization, frequency of utilization and the number of applications or software used.

3. Based on the theory put forward by Triandis (1980), the framework of research by Thompson et al (1991) and the results of previous studies, there are six factors that influence the use of information technology, namely social factors, affect, complexity, task suitability, consequences. long-term and facilitating conditions.

4. Social factors relate to the individual's internalization of reference to subjective cultural groups and specifying the interpersonal agreement that individuals have attempted with others in special social situations. Subjective culture contains norms (norms), roles (roles) and values (values). The affect factors are feelings of joy, joy, pleasure or depression, disgust, displeasure and hate associated with certain individuals in the use of information technology. Complexity is defined as the level of innovation that is perceived as relatively difficult to understand and use. Task suitability relates to the extent to which an individual's ability to use information technology to improve individual performance in carrying out tasks. Long-term consequences are defined as the results obtained in the future, such as increased flexibility, changing jobs or increased opportunities for more meaningful jobs. Facilitating conditions are defined as objective factors outside the environment that make it easier for the user to act / work. 


\section{References}

[1] Barua, Krebel dan Mukhopadhyay. (1995). Information Technologies and Business Value : An Analytic and Empirical Investigation. Information System Research. March 1995

[2] Bodnar dan Hopwood. (1995). Accounting Information System. Prentice Hall Inc. 1995

[3] Bryjolfsson dan Hitt. (1996). Paradox Lost? Firm Level Evidence on Return to Information System. Management Science. 1996

[4] Burnkrant dan Page. (1982). An Examination of Discriminant and Predictive Validity of Fishbein's Behavioral Intention Model. Journal of Marketing Research. November 1982

[5] Davis F.D. (1989). Perceived Usefulness, Perceived Ease of Use and User Acceptance of Information Technology. MIS Quarterly. September 1989.

[6] Davis F.D, Bagozzi Richard P dan Warshaw Paul R. (1989). User Acceptance of Computer Technology : A Comparison of Two Theoretical Model. Management Science. August 1989.

[7] Fishbein dan Ajzen. (1975). Belief Attitude, intentions and Behavior : An Introduction to Theory and Research. Addison-Wissley. Boston. Ma. 1975.

[8] Goodhue Dale dan Thompson Ronald. (1995). Task Technology Fit and Individual Performance. MIS Quarterly. June 1995.

Grover dan Goslar. (1993). The Initiation, Adoption and Implementation of Telecommunications Technologies in US Organization. Journal of Management Information System. Vol 10. 1993.

[9] Jackson,Simeon dan Leitch Robert. (1997) Toward an Understanding of the Behavioral Intention to Use an Information System. Decision Sciences. Spring 1997.

[10] Lucas Hernt C. (1978). Empirical Evidence for A Descriptive Model of implementation. MIS Quarterly. June 1978.

[11] Lucas Hernt C dan Spitler VK. (1999). Technology Use and Performance : A field Study of Broker Workstation. Decisions Sciences. Spring 1999.

[12] Maahmod Mo Adam dan Mann Gary. (1993). Special Issue : Impact of Information Technology Investment on Organizational Performance. Journal of Management Information System. 1993

[13] Mitra Sabyasachi dan Chaya Antonie Karim. (1996). Analyzing Cost Effectiveness of Organizations : The Impact of Organization Technology Spending. Journal of Management Information System. Fall. 1996.

[14] Mortensen Erick. (1988). Personal Computers : Tools Par Excellence. The office. August 1988. 
[15] Rahmi Qadri. (1997). Pengaruh Faktor Sosial, Affect, Konsekuensi yang dirasakan dan Kondisi yang Memfasilitasi terhadap Pemanfaatan Komputer. Tesis S2 UGM. 1997.

[16] Rai A Patnayakuni R dan Patnayakuni N. (1997). Technology Investment and Business Performance. Communication of the ACM. 1997.

[17] Rifa Dandes. (1998). Pengaruh Faktor Demografi dan Personality terhadap Keahlian dalam End User Computing (EUC). Tesis S2 UGM. 1998.

[18] Roach S. (1991). Service Under Siege : The Restructuring Imperative. Harvard Business Review. September-Oktober. 1991

[19] Robey D. User Attitudes and Management Information System Use. Academy of Management Journal. September 1979.

[20] Sabherwal R and William King. (1992). Decision Processes for Developing Strategic. Application of Information of Information system : A Contingency Approach. Decision Science. 1992.

[21] Schultz dan Slevin. (1975). Implementation and Organizational Validity : An empirical Investigation. Implementation Of Operation Research Management Science. New York. 1975

[22] Strassman Paul.(1996). Spending without Result. Computerworld.April 1996

[23] Sugeng dan Nur Indriantoro. (1998). Peran Faktor Kecocokan Tugas-Teknologi dalam Memperoleh Pengaruh Positif Teknologi Informasi Terhadap Kinerja Individual. Jurnal Ekonomi dan Bisnis Indonesia. 1998.

[24] Sylvia. (2001). Pemanfaatan Teknologi Audit Untuk Mencapai Efektivitas Audit dan Efisiensi Biaya. Kompak. Januari 2001

[25] Teddy Jurnali. (2001). Analisis Pengaruh Faktor Kesesuaian Tugas-Teknologi dan Pemanfaatan Teknologi Informasi Terhadap Kinerja Akuntan Publik. Simposium Nasional Akuntansi IV. 2001

[26] Thai Fung Jin. (2002). Analisis Faktor-Faktor yang Mempengaruhi Pemanfaatan Teknologi Informasi dan Pengaruh Pemanfaatan Teknologi Informasi Terhadap Kinerja Akuntan Publik. Tesis S2 UGM. 2002.

[27] Thompson Ronald, Christoper A and Howell Jane. (1991). Personal Computing : Toward a Conceptual Model of Utilization. MIS Quarterly. March 1991 (1994). Influence of Experience on Personal Computer Utilization : testing A Conceptual Model. Journal of Management Information Systems. 1994

[28] Tornatzky dan Klein. (1982). Innovation Characteristics and Innovation Adoption Implementation : A meta Analysis of Findings. IEEE Transaction on Engineering Management. February 1982.

[29] Triandis HC. (1980). Values, Attitudes and Interpersonal Behavior. University of Nebraska Press. Lincoln. NE. 1980. 